\title{
Antimicrobial Activity of Hemolymph and Venom Obtained from Some Scorpion Species
}

\section{Bazı Akrep Türlerinden Elde Edilen Hemolenf ve Zehrin Antimikrobiyal Aktivitesi}

\author{
Halil Koç ${ }^{1}$, Cumhur Avşar ${ }^{1 \oplus}$ and Yusuf Bayrakcı ${ }^{\circledR}$ \\ ${ }^{1}$ Department of Biology, Faculty of Arts and Science, Sinop University, Sinop, Turkey. \\ ${ }^{2}$ Department of Biology, Faculty of Science, Ege University, İzmir, Turkey.
}

\section{A B STR ACT}

\begin{abstract}
The aim of this study was to determine the antibacterial and antifungal activities of hemolymph and venom obtained from some scorpion species. Venom samples were obtained by electrical stimulation method from five different scorpion species. Again, hemolymph fluids were obtained from five different scorpion species. Antimicrobial activities of hemolymph and venom diluted 1:1 with sterile saline were tested against a total of 10 microorganisms including seven bacteria and three yeasts using disc diffusion method. Venom samples of Protoiurus kraepelini showed inhibition zones of 9-20 mm on all microorganisms tested. Venom from this species has the highest antibacterial activity against Bacillus subtilis. The venom samples of Aegaeobuthus gibbosus were effective (7-12 mm) on all microorganisms except Enterococcus faecalis and Micrococcus luteus. In addition, it was found that venoms obtained from Androctonus crassicauda, Hottentotta saulcyi and Leiurus abdullahbayrami have different levels of antibacterial effect but no antifungal effect against Candida species. Scorpion hemolymphs have been shown to have similar effects against Gram-positive and Gram-negative bacteria. Besides, the obtained hemolymphs have been found to have low effect (7-9 mm) on microorganisms.
\end{abstract}

\section{Key Words}

Scorpion, antimicrobial activity, venom, hemolymph.

\section{öz}

u çalışmanın amacı, bazı akrep türlerinden elde edilen hemolenf ve zehirlerin antibakteriyal ve antifungal özelliklerinin belirlenmesidir. Zehir örnekleri elektrik stimülasyonu yöntemiyle beş farklı akrep türünden elde edilmiştir. Bununla birlikte hemolenf sıvısı da beş farklı akrep türünden elde edilmiştir. 1:1 oranında tuz solüsyonu ile seyreltilen hemolenf ve zehirlerin antimikrobiyal aktiviteleri yedi bakteri ve üç mayadan oluşan 10 mikroorganizmaya karşı disk difüzyon yöntemi ile test edilmiştir. Protoiurus kraepelini'den elde edilen zehir örnekleri test edilen bütün mikroorganizmalar üzerinde 9-20 mm inhibisyon zonu meydana getirmiştir. Bu türden elde edilen zehir Bacillus subtilis'e karşı en yüksek antibakteriyal aktivite gösteren örnek olmuştur. Mesobuthus gibbosus'dan alınan zehir örnekleri Enterococcus faecalis ve Micrococcus luteus haricindeki tüm mikroorganizmalarda etkili (7-12 mm) olmuştur. Ayrica, Androctonus crassicauda, Hottentotta saulcyi ve Leiurus abdullahbayrami'den elde edilen zehirler farklı düzeylerde antibakteriyal etkiye sahip olmakla birlikte Candida türleri üzerinde antifungal bir etkisi olmamıştır. Akrep hemolenflerinin Gram-pozitif ve Gram-negatif bakteriler üzerinde benzer etkilerinin olduğu gösterilmiştir. Bunun yanında, elde edilen hemolenflerin mikroorganizmalar üzerinde düşük etkiye (7-9 mm) sahip olduğu tespit edilmiştir.

\section{Anahtar Kelimeler}

Akrep, antimikrobiyal aktivite, zehir, hemolenf.

Article History: Received: Nov 19, 2019; Revised: Jun 19, 2020; Accepted: Jun 19, 2020; Available Online: Sep $28,2020$.

DOI: https://doi.org/10.15671/hjbc.646190

Correspondence to: Halil Koç, Department of Biology, Faculty of Arts and Science, Sinop University, Sinop, Turkey.

E-Mail: koc.halil@hotmail.com 


\section{INTRODUCTION}

The war between human beings and bacteria continues. On the one hand, while trying to defend against bacterial infections with appropriate antibiotics, on the other hand, bacteria respond with a resistance to these defence mechanisms of antibiotics [1]. The increased resistance of microorganisms to existing antibiotics used for treatment and the high cost of producing new generation antibiotics necessitates the discovery and construction of new antimicrobial agents for the pharmaceutical industry [2]. As a result of different studies, peptides having antimicrobial activity have been obtained from bacteria, scorpions, different insect sets, spiders, various crustaceans, amphibians, mammals and even natural sources [3]. Antimicrobial peptides are evolutionarily old weapons. The wide distribution within the animal kingdom supports that antimicrobial peptides play an important role in successfully evolving multicellular organisms from the evolutionary process $[4,5]$. The first antimicrobial peptides were identified from Hyalophora cecropia, a butterfly species [6]. Several antimicrobial peptides have been obtained from venom and hemolymphs of arthropods such as spiders and scorpions [7]. Scorpion venom is an integrated library of proteins and peptides that may be candidates for drug design and development, as well as toxicological responses [8]. The general composition of scorpion venom varies between different families. In addition, these differences in the composition of scorpion venom can be examined from genus to genus and even between different species within a genus $[8,9]$. Scorpion venom is a mixture of peptide, protein, neurotoxin and salt. These venoms have been evaluated as potential therapeutics against many diseases such as cancer, viral and microbial from past to present [10].

The purpose of this study was to determine the antibacterial and antifungal activities of hemolymphs and venoms extracted from some scorpions against seven bacterial strains; six Gram-positive (Micrococcus luteus ATCC 9345, Staphylococcus aureus ATCC 6538, Bacillus sphaericus ATCC 2362, B. subtilis, B. cereus ATCC 7064 and Enterococcus faecalis ATCC 51299) and one Gramnegative (Escherichia coli ATCC 11293) and three yeasts (Candida krusei ATCC 6258, C. parapsilosis ATCC 22019 and C. albicans ATCC 14053).

\section{MATERIALS and METHODS}

\section{Scorpion Collection and Venom Extraction}

Scorpions were collected in Muğla, Artvin, Gaziantep, Şanlıurfa and Mardin provinces, in Turkey as shown in Figure 1. Venom samples were extracted from Androctonus crassicauda, Hottentotta saulcyi, Leiurus abdullahbayrami, Aegaeobuthus gibbosus (Buthidae) and Protoiurus kraepelini (Iuridae) by electrically stimulating at the tail segments [11] The hemolymph samples were drawn from Calchas nordmanni (luridae), Scorpio maurus (Scorpionidae), Buthacus macrocentrus, Mesobuthus phillipsi and A. gibbosus (Buthidae) with a thin needle fixed to a sterile disposable syringe. As soon as venom and hemolymph samples were taken, they were diluted $1: 1$ with sterile $0.9 \% \mathrm{NaCl}$ solution and antimicrobial activity studies were started.

\section{Microorganisms}

The test organisms such as six Gram-positive bacteria (Micrococcus luteus ATCC 9345, Staphylococcus aureus ATCC 6538, Bacillus sphaericus ATCC 2362, B. subtilis, B. cereus ATCC 7064 and Enterococcus faecalis ATCC 51299), one Gram-negative bacteria (Escherichia coli ATCC 11293) and 3 yeast species (Candida krusei ATCC 6258 and Candida parapsilosis ATCC 22019 and C. albicans ATCC 14053) were used as the bacterial and fungal test organisms.

\section{Antibacterial and Antifungal Activities}

Antimicrobial effects of venom and hemolymph samples were performed by disc diffusion technique [12]. All microorganisms were stored at $-80^{\circ} \mathrm{C}$ in Mueller Hinton Broth (MHB) for bacteria and Sabouraud Dextrose Broth (SDB) for yeast (Difco) containing $15 \%(\mathrm{v} / \mathrm{v})$ glycerol. Fresh overnight (at $37^{\circ} \mathrm{C}$ ) cultures of all microorganisms were prepared prior to testing. Then, the turbidity was adjusted equivalent to $0.5 \mathrm{McF} F$ rland standards. After Mueller Hinton and Sabourd Dextrose Agar are prepared, $100 \mu \mathrm{l}$ of microorganisms was spread over the surface of an agar plate. The sterile empty antibiotic discs (Oxoid) were soaked with $20 \mu \mathrm{l}$ of extract and placed on the surface of the freshly inoculated medium. The media were incubated for $18-24 \mathrm{~h}$ at $35 \pm 0.5^{\circ} \mathrm{C}$ (for bacteria) and $48-72 \mathrm{~h}$ at $25 \pm 1^{\circ} \mathrm{C}$ (for fungus). Commercial antibiotic discs were used as control, and negative controls were to water. The antimicrobial effect was evaluated by measuring the diameter of inhibition zone. The values were expressed as mean \pm standard deviation (SD). 


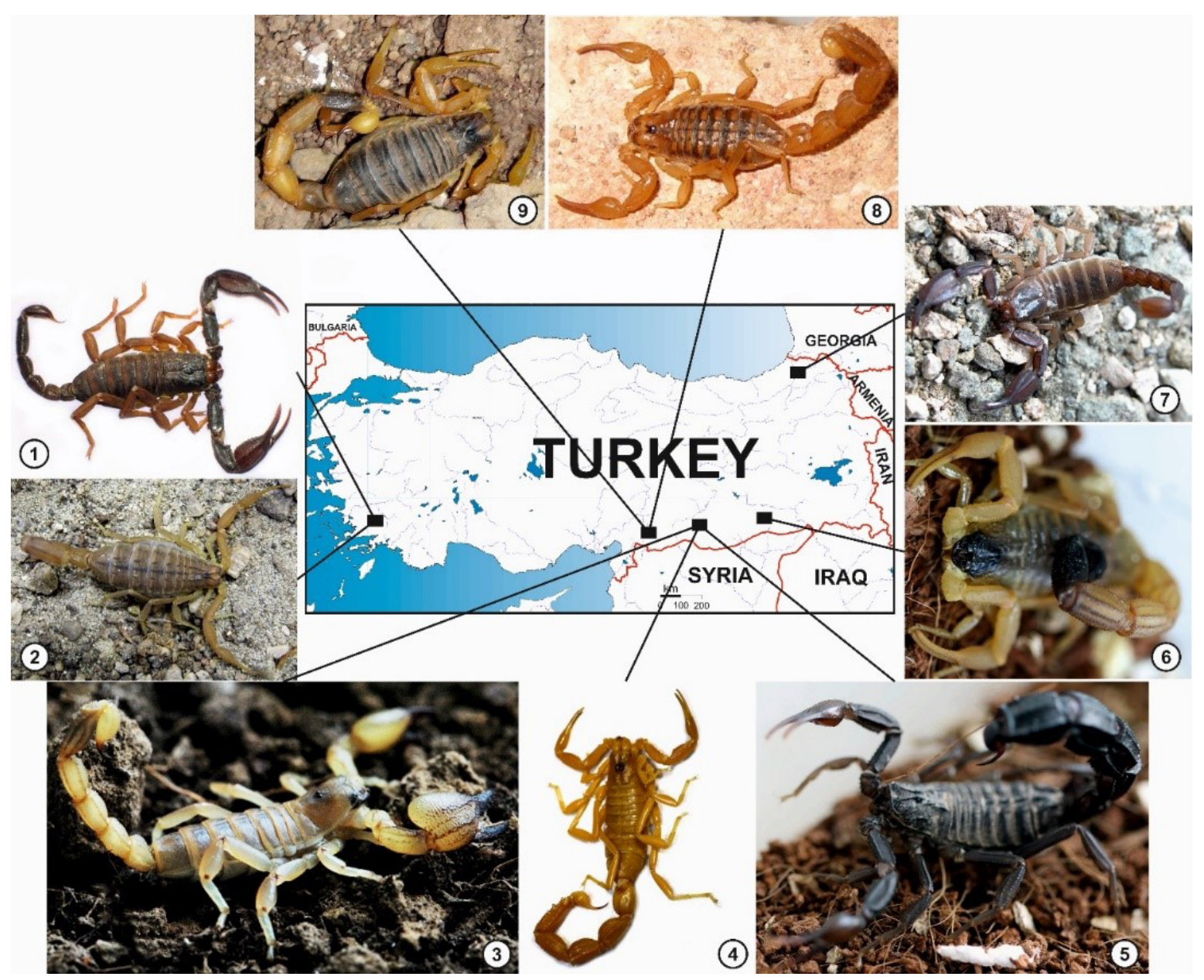

Figure 1. Map showing the localities of the scorpions collected for this study: 1. Protoiurus kraepelini (Muğla Province, Yatağan District) 2. Aegaeobuthus gibbosus (Muğla Province, Yatağan District), 3. Scorpio maurus (Şanlıurfa Province, Birecik District), 4. Buthacus macrocentrus (Şanlıurfa Province, Birecik District), 5. Androctonus crassicauda (Şanlıurfa Province, Ceylanpınar District), 6. Hottentotta saulcyi (Mardin Province, Central District), 7. Calchas nordmanni (Artvin Province, Central District), 8. Mesobuthus phillipsi (Gaziantep Province, Şehitkamil District) and 9. Leiurus abdullahbayrami (Gaziantep Province, Şehitkamil District).

\section{RESULTS and DISCUSSION}

In antimicrobial activity experiments for scorpion venom, inhibition zones ranging from $9-20 \mathrm{~mm}$ were determined on all microorganisms tested for P. kraepelini venom. Venom from this species has the highest antibacterial activity against $B$. subtilis. It was found that the venom obtained from $A$. gibbosus was effective on all microorganisms (7-12 $\mathrm{mm}$ ) except $E$. faecalis and $M$. luteus. In addition, it was found that venoms obtained from A. crassicauda, H. saulcyi and L. abdullahbayra$m i$ have different levels of antibacterial effect but no antifungal effect against Candida species (Figure 2A and Table 1). In the studies with $B$. macrocentrus and $M$. phillipsi hemolymph, zone diameters ranging from 7-9 $\mathrm{mm}$ were measured on all bacteria except $B$. cereus and $B$. sphaericus. In the experiment with $A$. gibbosus hemolymph, a diameter of $7 \mathrm{~mm}$ was determined on bacteria other than B. cereus, B. sphaericus and E. coli. C. nordmanni hemolymph 7-8 $\mathrm{mm}$ against $B$. subtilis, $B$. sphaericus and E. faecalis; $S$. maurus hemolymph produced zone diameters ranging from 7-9 $\mathrm{mm}$ on $S$. aureus, B. sphaericus and E. coli. As a result of the tests, scorpion hemolymphs have a very low and similar effect against Gram-positive and Gram-negative bacteria. In addition, the efficacy of the obtained hemolymphs against $B$. cereus and yeasts was not determined (Figure $2 B$ and Table 1). 
Table 1. Antimicrobial effects of scorpion venom and hemolymph.

\begin{tabular}{|c|c|c|c|c|c|c|c|c|c|c|c|c|c|c|c|c|}
\hline \multirow[b]{2}{*}{ 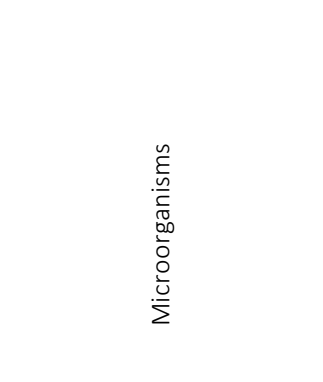 } & \multicolumn{5}{|c|}{ Scorpion venom } & \multicolumn{5}{|c|}{ Hemolymph } & \multicolumn{6}{|c|}{ Positive control } \\
\hline & 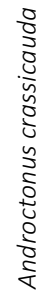 & $\begin{array}{l}\bar{a} \\
\frac{u}{3} \\
0 \\
0 \\
0 \\
\pm \\
0 \\
0 \\
0 \\
0 \\
0 \\
0\end{array}$ & 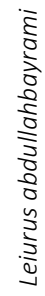 & 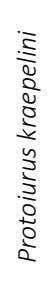 & 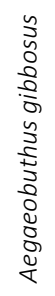 & $\begin{array}{l}\bar{a} \\
\frac{1}{0} \\
\frac{1}{0} \\
0 \\
0 \\
0 \\
0 \\
\frac{d}{0} \\
0\end{array}$ & 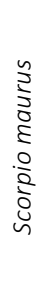 & 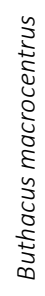 & 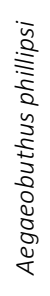 & 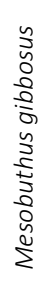 & 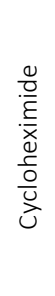 & 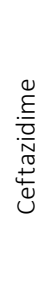 & 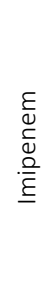 & 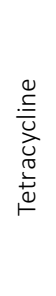 & 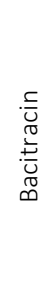 & $\begin{array}{l}\infty \\
\text {. } \\
x \\
\hat{x} \\
\text { हो } \\
0\end{array}$ \\
\hline M. luteus ATCC 9345 & 8 & - & - & 12 & - & - & - & 8 & 8 & 7 & - & 17 & 44 & 32 & 17 & 24 \\
\hline S. aureus ATCC 6538 & - & 7 & - & 14 & 7 & - & 9 & 9 & 8 & 7 & - & 24 & 40 & 32 & 7 & 11 \\
\hline B. sphaericus ATCC 2362 & 11 & 10 & 13 & 14 & 12 & - & 9 & - & - & - & - & 10 & 27 & 29 & 8 & 9 \\
\hline B. subtilis [c] & 8 & 7 & - & 20 & 12 & 8 & - & 7 & 7 & 7 & - & 9 & 28 & 30 & 8 & 10 \\
\hline B. cereus ATCC 7064 & 14 & 8 & - & 9 & 8 & 8 & - & - & - & - & - & 9 & 36 & 32 & 8 & 9 \\
\hline E. feacalis ATCC 51299 & - & 8 & - & 11 & - & 7 & - & 9 & 8 & 7 & - & 18 & 31 & 27 & - & - \\
\hline E. coli ATCC 11293 & 7 & - & - & 12 & 8 & - & 7 & 8 & 8 & - & - & 29 & 28 & 29 & 7 & 15 \\
\hline C. albicans ATCC 14053 & - & - & - & 10 & 8 & - & - & 9 & 8 & 7 & 42 & - & - & - & - & - \\
\hline C. krusei ATCC 6258 & - & - & - & 10 & 8 & - & - & 8 & 8 & 7 & 43 & - & - & - & - & - \\
\hline C. parapilopsis ATCC 22019 & - & - & - & 9 & 7 & - & - & 8 & 8 & 7 & 40 & - & - & - & - & - \\
\hline
\end{tabular}

“-“not effect. The tests were performed twice and the same result was obtained. Therefore, no standard deviation ( \pm ) is given.

Researches on scorpion venom continue with new contributions in many areas, some of which are as follows; Díaz-García et al. [13] reported that Rhopalurus junceus scorpion venom does not affect normal cells but has selective toxicity on epithelial cancer cells. Guo et al. [14] studied the effects of different types of Brazilian yellow scorpion Tityus serrulatus venom on human squamous carcinoma cell line, PC3 cell line, human breast cancer cell line, and human glioblastoma cell line and reported that venoms have anticancer effect. Al Asmari and Khan [15] studied the antitumor effect of the venom of Leiurus quinquestriatus on the chemical effect of skin cancer in mice and obtained positive results. Akef et al. [16] found that Androctonus amoreuxi scorpion venom has cytotoxic and antiproliferative effects against prostate cancer. Besides the anticancer effect studies of scorpion venom, antimicrobial effect researches have been carried out successfully. Almaaytah et al. [17] reported that two different peptide types of $A$. amoreuxi scorpion venom have antimicrobial effect at concentrations between 20 and $150 \mathrm{mM}$ on Gram-positive S. aureus, Gram-negative E. coli and C. albicans. Cao et al. [18] investigated the antibacterial effects of $\mathrm{Kn} 2-7$ and BmKn2 peptides from scorpion venom and found activity against many Gram-positive and negative bacteria. Ramírez-Carreto et al. [19] emphasized that the two different peptide types of scorpion venom Vaejovis mexicanus smithi have antibacterial effects on clinical strains S. aureus, B. subtilis, E. coli, S. typhi, P. aeruginosa and Streptococcus agalactiae. Guo et al. [14] reported that $T$. serrulatus scorpion venom has antibacterial and antifungal effects as well as anticancer effect. Especially its low concentration effect on S. aureus was remarkable. Arpornsuwan et al. [20] reported that different peptide types of the scorpion venom of Opisthacanthus madagascariensis have antibacterial effects at different concentrations on Grampositive methicillin-resistant $S$. aureus, $S$. aureus, S. epidermidis and B. subtilis. Bao et al. [21] reported that opisin obtained from Opistophthalmus glabrifrons scorpion venom had higher antibacterial effect against Gram-positive than Gram-negative. Ahmed et al. [22] in their study on the antibacterial activity of the Heterometrus xanthopus venom, they carried out the study by diluting the venom with distilled water in a ratio of $1 / 1,1 / 10$ and $1 / 100$. They could not detect any activity at $1 / 10$ and $1 / 100$ dilution. They found the highest activity at $1 / 1$ dilution on $B$. subtilis ATCC $6633(30 \pm 0.67 \mathrm{~mm})$. These results are consistent with our study. Ongoing studies on scorpion venom have been investigated not only in anticancer and antimicrobial issues, but also in antiviral effects. There have been many studies on this subject [23-27]. 


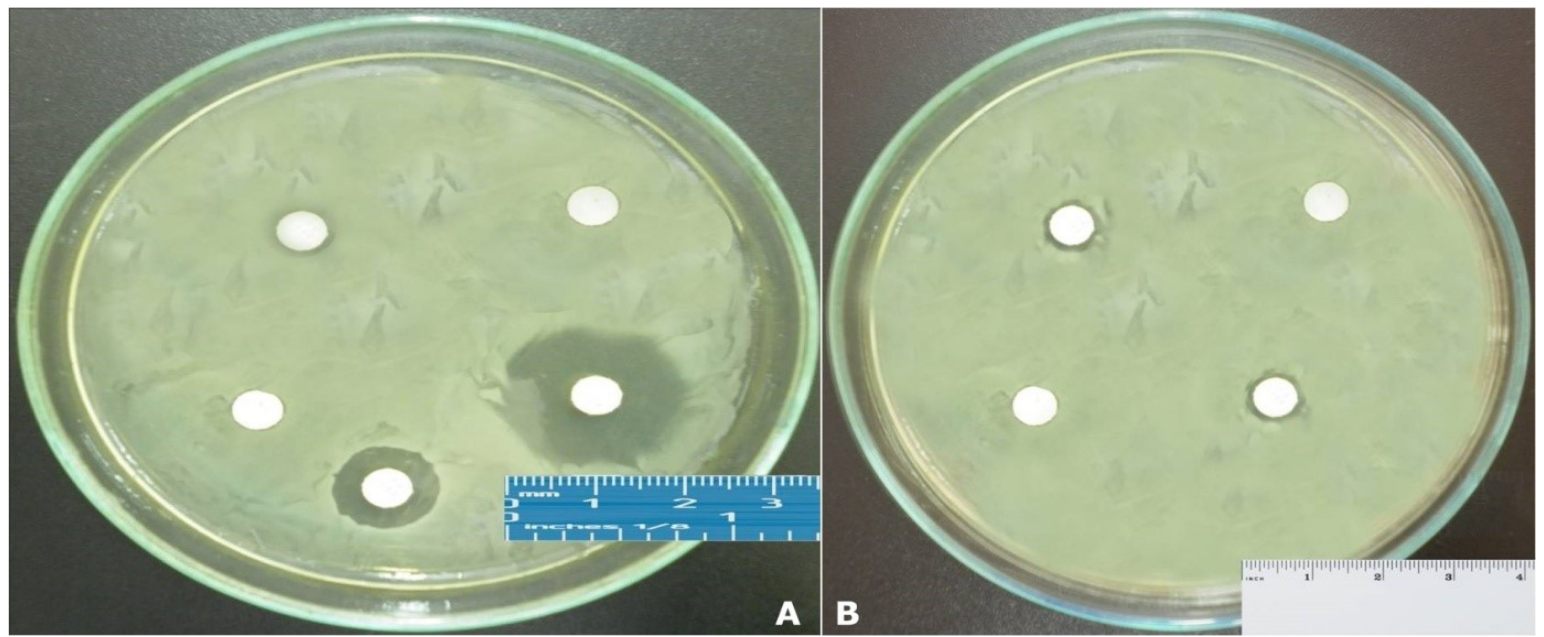

Figure 2. (A) Inhibition zone affected by venom samples of Protoiurus kraepelini, (B) An example of inhibition zone caused by hemolymphs.

\section{CONCLUSION}

The increasing resistance of microorganisms to antibiotics day by day, bring on the need for new pharmaceutical ingredients that are more effective against microorganisms. In our study, we have studied with venoms and hemolymphs that may be the source of these new pharmaceutical ingredients from various scorpion species. Antimicrobial activity tests of many scorpion hemolymph and venom were performed. Venom obtained from some scorpion species has been found to have broad spectrum antimicrobial effect. It is thought that the determination of the possible active substances that have antimicrobial activity contained in the venom and of their chemical structure will be important pharmacologically.

\section{Acknowledgments}

We wish to thank Dr. Ersen Aydın Yağmur for his help during the field trips and specimen collecting. Special thanks to Prof. Dr. İsmet BERBER (Late).

\section{References}

1. Z. Zhao, Y. Ma, C. Dai, R. Zhao, S. Li, Y. Wu, Z. Cao, W. Li, Imcroporin, a new cationic antimicrobial peptide from the venom of the scorpion Isometrus maculates, Antimic. Agents \& Chem., 53 (2009) 3472-3477.

2. R. Singh, H.S. Nalwa, Medical applications of nanoparticles in biological imaging, cell labeling, antimicrobial agents, and anticancer nanodrugs, J. Biomed. Nanotech., 7 (2011) 489-503.

3. N. Yiğit, Örümcek zehirlerinin antimikrobiyal aktivitesi, Mikrobiyo. Derg., 1 (2003) 1-9.
4. R. Samy, P. Gopalakrishnakone, M.M. Thwin, T.K.V. H. Chow, Bow, E.H. Yap, T.W.J. Thong, Antibacterial activity of snake, scorpion and bee venoms: a comparison with purified venom phospholipase A2 enzymes, J. App. Microbiol., 102 (2007) 650-659.

5. R.H. Qi, Y. Chen, Z.L. Guo, F. Zhang, Z. Fang, K. Huang, , H. Yu, Y.P. Wang, Identification and characterization of two novel cathelicidins from the frog Odorrana livida, Zool. Res., 40 (2019) 94.

6. H. Steiner, D. Hultmark, Å. Engström, H. Bennich, H.G. Boman, Sequence and specificity of two antibacterial proteins involved in insect immunity, Nature, 292 (5820) (1981) 246.

7. L. Kuhn-Nentwig, Antimicrobial and cytolytic peptides of venomous arthropods, CMLS, 60 (12) (2003) 2651-2668.

8. Y. Ma, R. Zhao, Y. He, S. Li, J. Liu, Y. Wu, Z. Cao, W. Li, Transcriptome analysis of the venom gland of the scorpion Scorpiops jendeki: implication for the evolution of the scorpion venom arsenal, BMC, 10 (2009) 290.

9. C.V.F. Batista, S.A. Román-González, S.P. Salas-Castillo, F.Z. Zamudio, F. Gómez-Lagunas, L.D. Possani, Proteomic analysis of the venom from the scorpion Tityus stigmurus: biochemical and physiological comparison with other Tityus species. Comp. Biochem. \& Physiol Part C, 146 (2007) 147157.

10. H.M. Akef, Anticancer and antimicrobial activities of scorpion venoms and their peptides, Toxin Reviews, 38 (2019) 41-53.

11. E. Zlotkin, A.S. Shulov, A simple device for collecting scorpion venom, Toxicon, 7 (1969) 331-332.

12. A.W. Bauer, W.M.M. Kirby, J.C. Sherris, M. Turck, Antibiotic susceptibility testing by a standardized single disk method, Am. J. Clin. Path., 45 (1966) 493-496.

13. Díaz-García, L. Morier-Díaz, Y. Frión-Herrera, H. RodríguezSánchez, Y. Caballero-Lorenzo, D. Mendoza-Llanes, J.A. Fraga-Castro, In vitro anticancer effect of venom from Cuban scorpion Rhopalurus junceus against a panel of human cancer cell lines, J. Ven. Res., 4 (2013) 5.

14. Y. Guo, S.L. Liu, W.Z. Ju, C.Y. Li, P. Cao, Analgesic-antitumor peptide induces apoptosis and inhibits the proliferation of SW480 human colon cancer cells, Oncol. Let., 5 (2013) 483488. 
15. A.K. Al Asmari, A.Q. Khan, Investigation of in vivo potential of scorpion venom against skin tumorigenesis in mice via targeting markers associated with cancer development Drug Des. Dev. Ther., 10 (2016) 3387.

16. H. Akef, N. Kotb, D. Abo-Elmatty, S. Salem, Anti-proliferative effects of Androctonus amoreuxi Scorpion and Cerastes cerastes snake venoms on human prostate cancer cells, J. Cancer Prev., 22 (2017) 40

17. Almaaytah, M. Zhou, L. Wang, T. Chen, B. Walker, C. Shaw, Antimicrobial/cytolytic peptides from the venom of the North African scorpion, Androctonus amoreuxi: biochemical and functional characterization of natural peptides and a single site-substituted analog, Peptides, 35 (2012) 291-299.

18. L. Cao, C. Dai, Z. Li, Z. Fan, Y. Song, Y. Wu, W. Li, Antibacterial activity and mechanism of a scorpion venom peptide derivative in vitro and in vivo, PloS one, 7 (2012) e40135.

19. S. Ramírez-Carreto, V. Quintero-Hernández, J.M. JiménezVargas, G. Corzo, L.D. Possani, B. Becerril, E. Ortiz, Gene cloning and functional characterization of four novel antimicrobial-like peptides from scorpions of the family Vaejovidae, Peptides, 34 (2012) 290-295.

20. T. Arpornsuwan, W. Sriwai, J. Jaresitthikunchai, N Phaonakrop, H. Sritanaudomchai, S. Roytrakul, Anticancer activities of antimicrobial BmKn2 peptides against oral and colon cancer cells, Int. J. Pept. Res. Ther., 20 (2014) 501-509.

21. Bao, J. Zhong, X.C. Zeng, Y. Nie, L. Zhang, Z.F. Peng, A novel cysteine-free venom peptide with strong antimicrobial activity against antibiotics-resistant pathogens from the scorpion Opistophthalmus glabrifrons, J. Peptide Sci., 21 (2015) 758-764.
22. U. Ahmed, N.K. Malik Mujaddad-ur-Rehman, S.A. Fawad, A. Fatima, Antibacterial activity of the venom of Heterometrus xanthopus, Ind. J. Pharm., 44 (2012) 509.

23. W. Hong, R. Zhang, Z. Di, Y. He, Z. Zhao, J. Hu, Y. Wu, W. Li, $Z$. Cao, Design of histidine-rich peptides with enhanced bioavailability and inhibitory activity against hepatitis $C$ virus, Biomaterials, 34 (2013) 3511-3522.

24. W. Hong, T. Li, Y. Song, R. Zhang, Z. Zeng, S. Han, X. Zhang, Y. Wu, W. Li, Z. Cao, Inhibitory activity and mechanism of two scorpion venom peptides against herpes simplex virus type 1, Antivir. Res., 102 (2014) 1-10.

25. A.M. El-Bitar, M.M. Sarhan, C. Aoki, Y. Takahara, M. Komoto, L. Deng, M.A. Moustafa, H. Hotta, Virocidal activity of Egyptian scorpion venoms against hepatitis C virus, Virol. J., 12 (2015) 47.

26. R. Zabihollahi, K.P. Bagheri, Z. Keshavarz, F. Motevalli, G. Bahramali, S.D. Siadat, S.B. Momen, D. Shahbazzadeh, M.R. Aghasadeghi, Venom components of Iranian scorpion Hemiscorpius lepturus inhibit the growth and replication of human immunodeficiency virus 1 (HIV-1), Iran. Biomed. J., 20 (2016) 259.

27. Zeng, Z., Zhang, Q., Hong, W., Xie, Y., Liu, Y., Li, W., Wu, Y., Cao, Z. A scorpion defensin BmKDfsin4 inhibits hepatitis B virus replication in vitro, Toxins, 8 (2016) 124. 